\title{
The effect of activating solution on the mechanical strength, reaction rate, mineralogy, and microstructure of alkali-activated fly ash
}

\author{
Y. Ma $\cdot$ J. Hu $\cdot$ G. Ye
}

Received: 16 November 2011 / Accepted: 1 February 2012/ Published online: 16 February 2012

(C) The Author(s) 2012. This article is published with open access at Springerlink.com

\begin{abstract}
Alkali-activated fly ash (AAF) is a promising material that exhibits comparable material properties as cement-based materials but with much less $\mathrm{CO}_{2}$ emission. In the present work, the effect of activating solution $\left(\mathrm{SiO}_{2}\right.$ and $\mathrm{Na}_{2} \mathrm{O}$ content) on the performance of AAF was studied by means of isothermal calorimetry and $\mathrm{X}$-ray diffraction analysis. Meanwhile, the pore structure of AAF was examined by mercury intrusion porosimetry combined with environmental scanning electron microscope. The results indicate that increasing the sodium oxide content leads to a higher extent of reaction, denser matrix and higher possibility of crystallization, corresponding to a higher compressive strength of AAF. The addition of silica in the alkaline solution retards the reaction rate and zeolite formation, while improves the microstructure of the matrix. Therefore, there is an optimal value for $\mathrm{SiO}_{2}$ with respect to the $\mathrm{Na}_{2} \mathrm{O}$ content for the AAF in this study.
\end{abstract}

\section{Introduction}

The production of ordinary Portland cement contributes to approximately $5 \%$ of the global greenhouse gas emission $[1,2]$. From a sustainable development aspect, partially replacement of the Portland cement by industry byproducts, e.g., fly ash and blast furnace slag, can considerably

Y. Ma $(\bowtie) \cdot$ J. Hu $\cdot$ G. Ye

Section Materials and Environment, Faculty of Civil Engineering and Geosciences, CiTG, Delft University of Technology, Stevinweg 1, 2628CN Delft, The Netherlands e-mail: yuwei.ma@tudelft.nl

G. Ye

Department of Structural Engineering, Ghent University, Ghent, Belgium reduce the $\mathrm{CO}_{2}$ emission [3]. Therefore, numerous studies are reported on the development of fly ash utilization in cement-based materials [4-6]. However, in the condition of alkali environment (between 12.6 and 13.5 [7]) and curing temperature of $20{ }^{\circ} \mathrm{C}$ in cement-based materials system, the pozzolanic reaction rate of fly ash is quite low $[8,9]$. As a result, most of the fly ash just acts as fillers in cementbased materials.

In recent years, a new application of fly ash as construction materials by the alkali activated technology has been widely investigated [10-13]. Alkali-activated fly ash (AAF) refers to an amorphous aluminosilicate material synthesized by the reaction between fly ash and aqueous hydroxide or alkali silicate solution. It is also named as "geopolymer" [14], "inorganic polymers" [15] and "inorganic polymer glasses" [16-18]. Similar to the calcium silicate hydrate $(\mathrm{C}-\mathrm{S}-\mathrm{H})$ gel in Portland cement hydrates, an alkali aluminosilicate gel is generated during the geopolymerization. The framework of the aluminosilicate gel is a highly connected three-dimensional network of aluminates and silicate tetrahedra, with the negative charge balanced by the alkali metal cations [19]. The hardened gel provides most of the strength just like the role of $\mathrm{C}-\mathrm{S}-\mathrm{H}$ gel in Portland cement hydrates. Therefore, the primary application of AAF lies in the environmental friendly alternative to Portland cement.

It is generally accepted that the engineering properties of AAF are significantly affected by the activating solutions (refer to activator). Fernández-Jiménez et al. [20] have found that the matrix generated by potassium compounds is more porous than by sodium compounds, resulting in a lower compressive strength. It is also illustrated by other authors [21-23] that more $\mathrm{Na}_{2} \mathrm{O}$ content in activator leads to a higher compressive strength of AAF. When silica is also presented in the activator, the $\mathrm{SiO}_{2} /$ 
$\mathrm{Na}_{2} \mathrm{O}$ ratio is reported to significantly influence the performance of AAF [24, 25]. Table 1 listed the detail information about the fly ash, activator, curing condition, and optimal content of activator summarized from recent studies on AAF. It is important to notice that by using fly ash with different chemical compositions and curing conditions, the optimal $\mathrm{SiO}_{2} / \mathrm{Na}_{2} \mathrm{O}$ ratio is quite different [21, 24, 25]. Fernández-Jiménez et al. [26] have compared several types of fly ash and conclude that the reactive silica, reactive aluminum, particle size distribution are all key factors in determining the potential reactivity of fly ash for being alkali activated. For this reason, the optimal mixture of activator varies in different studies.

This work is a preliminary study of a 4 years research project on the engineering properties of AAF as an alternative material to ordinary Portland cement. In this project, a local Class-F fly ash (obtained from The Netherlands) was applied to synthesize AAF. It is essential to determine the optimal activator for this fly ash before other engineering properties (e.g., durability or shrinkage) are evaluated. In this study, the effect of sodium oxide and soluble silica content on the mechanical properties, reaction rate, mineralogy, and morphology of AAF was studied by means of isothermal calorimetry, X-ray diffraction analysis (XRD), and environmental scanning electron microscope (ESEM), respectively. Furthermore, together with ESEM, the pore structure of AAF was also investigated by mercury intrusion porosimetry (MIP).

\section{Materials and methods}

\section{Materials}

The fly ash utilized in the present work was generated in a coal-fired power plant in The Netherlands (type F according to the ASTM classification). The chemical composition determined by X-ray fluorescence (XRF) is presented in Table 2 and the particle size distribution is shown in Fig. 1. The mean ash particle diameter of fly ash is $21.46 \mu \mathrm{m}$ and surface area measured by nitrogen adsorption is $1,600 \mathrm{~m}^{2} /$ kg. XRD (Fig. 2) revealed that the major crystalline phases in fly ash are quartz $\left(\mathrm{SiO}_{2}\right)$ and mullite $\left(3 \mathrm{Al}_{2} \mathrm{O}_{3}, 2 \mathrm{SiO}_{2}\right)$.

The alkaline solutions were prepared by mixing sodium hydroxide (analytical grade, $>98 \%$ purity) with distilled water and sodium silicate solution $\left(\mathrm{Na}_{2} \mathrm{O}: 8.25 \mathrm{wt} \%, \mathrm{SiO}_{2}\right.$ : $27.50 \mathrm{wt} \%$ ). A series of activating solutions with different $\mathrm{SiO}_{2}$ and $\mathrm{Na}_{2} \mathrm{O}$ content were prepared in this study. The $\mathrm{SiO}_{2}$ content was in the range of $0-1.5 \mathrm{~mol} / \mathrm{kg}$ fly ash, and $\mathrm{Na}_{2} \mathrm{O}$ content was between 1.0 and $1.5 \mathrm{~mol} / \mathrm{kg}$ fly ash. The composition of alkali solution for each mixture is shown in Table 3. The water-to-fly ash mass ratio was kept constantly at 0.35 . Other mixtures, e.g., with higher $\mathrm{SiO}_{2}$ ( $2 \mathrm{~mol})$ or lower alkali $\mathrm{Na}_{2} \mathrm{O}(0.5 \mathrm{~mol})$ were also tried for comparison. However, some solutions $\left(\mathrm{SiO}_{2}=2.0 \mathrm{~mol}\right)$ were not stable with precipitation formed; other samples $\left(\mathrm{Na}_{2} \mathrm{O}=0.5 \mathrm{~mol}\right)$ could not set due to the low alkali content, which were not studied further.

Table 1 Detail information of AAF in previous studies

\begin{tabular}{|c|c|c|c|c|c|c|}
\hline \multirow{5}{*}{ Bakharev [21] } & \multicolumn{2}{|c|}{ Fly ash chemical composition } & \multicolumn{2}{|c|}{ Activating solution } & \multirow{2}{*}{$\begin{array}{l}\text { Curing condition } \\
75^{\circ} \mathrm{C} \text { till } 28 \text { days }\end{array}$} & \multirow{2}{*}{$\begin{array}{l}\text { Optimal mixture } \\
\mathrm{Na}_{2} \mathrm{O} \text { content } 8 \%\end{array}$} \\
\hline & $\mathrm{SiO}_{2}(\%)$ & 50.0 & $\mathrm{SiO}_{2}(\%)^{\mathrm{a}}$ & & & \\
\hline & $\mathrm{Al}_{2} \mathrm{O}_{3}(\%)$ & 28.0 & $\mathrm{Na}_{2} \mathrm{O}(\%)^{\mathrm{a}}$ & $2.0-8.0$ & & \\
\hline & Reactive $\mathrm{SiO}_{2}(\%)$ & & $\mathrm{SiO}_{2} / \mathrm{Na}_{2} \mathrm{O}$ & Constant at 2.02 & & \\
\hline & Reactive $\mathrm{Al}_{2} \mathrm{O}_{3}(\%)$ & & Water/FA & 0.30 & & \\
\hline \multirow{4}{*}{$\begin{array}{l}\text { Fernández-Jiménez } \\
\text { and Palomo [23] }\end{array}$} & $\mathrm{SiO}_{2}(\%)$ & 53.1 & $\mathrm{SiO}_{2}(\%)^{\mathrm{a}}$ & $0-9.52$ & \multirow[t]{4}{*}{$85^{\circ} \mathrm{C}$ for $20 \mathrm{~h}$} & \multirow{4}{*}{$\begin{array}{c}\mathrm{SiO}_{2} / \mathrm{Na}_{2} \mathrm{O}=0.118 \text { and } 1.23 \\
\text { with different sol./FA ratio }\end{array}$} \\
\hline & $\mathrm{Al}_{2} \mathrm{O}_{3}(\%)$ & 24.8 & $\mathrm{Na}_{2} \mathrm{O}(\%)^{\mathrm{a}}$ & $5.55-14.90$ & & \\
\hline & Reactive $\mathrm{SiO}_{2}(\%)$ & 50.4 & $\mathrm{SiO}_{2} / \mathrm{Na}_{2} \mathrm{O}$ & $0.037-1.28$ & & \\
\hline & Reactive $\mathrm{Al}_{2} \mathrm{O}_{3}(\%)$ & & Sol./FA ${ }^{\mathrm{c}}$ & $0.35 / 0.40$ & & \\
\hline \multirow[t]{4}{*}{ Škvára et al. [24] } & $\mathrm{SiO}_{2}(\%)$ & 51.9 & $\mathrm{SiO}_{2}(\%)^{\mathrm{a}}$ & & \multirow[t]{4}{*}{$80{ }^{\circ} \mathrm{C}$ for $12 \mathrm{~h}$} & \multirow{4}{*}{$\begin{array}{l}\mathrm{SiO}_{2} / \mathrm{Na}_{2} \mathrm{O}=1.1 \text { and } \mathrm{Na} 2 \mathrm{O} \\
\text { content } 7.5 \%\end{array}$} \\
\hline & $\mathrm{Al}_{2} \mathrm{O}_{3}(\%)$ & 32.8 & $\mathrm{Na}_{2} \mathrm{O}(\%)^{\mathrm{a}}$ & $5.0-9.0$ & & \\
\hline & Reactive $\mathrm{SiO}_{2}(\%)$ & & $\mathrm{SiO}_{2} / \mathrm{Na}_{2} \mathrm{O}$ & $0.9-1.9$ & & \\
\hline & Reactive $\mathrm{Al}_{2} \mathrm{O}_{3}(\%)$ & & Sol./FA & 0.30 & & \\
\hline \multirow[t]{4}{*}{ Criado et. al [25] } & $\mathrm{SiO}_{2}(\%)$ & 53.1 & $\mathrm{SiO}_{2}(\%)^{\mathrm{b}}$ & $0-9.07$ & \multirow[t]{4}{*}{$85^{\circ} \mathrm{C}$ till 180 days } & \multirow[t]{4}{*}{$\mathrm{SiO}_{2} / \mathrm{Na}_{2} \mathrm{O}=0.69$} \\
\hline & $\mathrm{Al}_{2} \mathrm{O}_{3}(\%)$ & 24.8 & $\mathrm{Na}_{2} \mathrm{O}(\%)^{\mathrm{b}}$ & Around 8 & & \\
\hline & Reactive $\mathrm{SiO}_{2}(\%)$ & 50.4 & $\mathrm{SiO}_{2} / \mathrm{Na}_{2} \mathrm{O}$ & $0.19-1.17$ & & \\
\hline & Reactive $\mathrm{Al}_{2} \mathrm{O}_{3}(\%)$ & & Sol./FA & 0.40 & & \\
\hline
\end{tabular}

\footnotetext{
${ }^{a}$ Weight ratio with respect to fly ash content

b Weight ratio with respect to activator content

c "Solution/fly ash" ratio (in weight)
} 
Table 2 Chemical composition of fly ash (wt\%) determined by XRF

\begin{tabular}{lllllllllll}
\hline Oxide & $\mathrm{SiO}_{2}$ & $\mathrm{Al}_{2} \mathrm{O}_{3}$ & $\mathrm{Fe}_{2} \mathrm{O}_{3}$ & $\mathrm{CaO}$ & $\mathrm{MgO}$ & $\mathrm{K}_{2} \mathrm{O}$ & $\mathrm{Na}_{2} \mathrm{O}$ & $\mathrm{TiO}_{2}$ & $\mathrm{P}_{2} \mathrm{O}_{5}$ & $\mathrm{SO}_{3}$ \\
\hline Weigth $(\%)$ & 48.36 & 31.36 & 4.44 & 7.14 & 1.35 & 1.64 & 0.72 & 1.24 & 1.90 & 1.18 \\
\hline
\end{tabular}

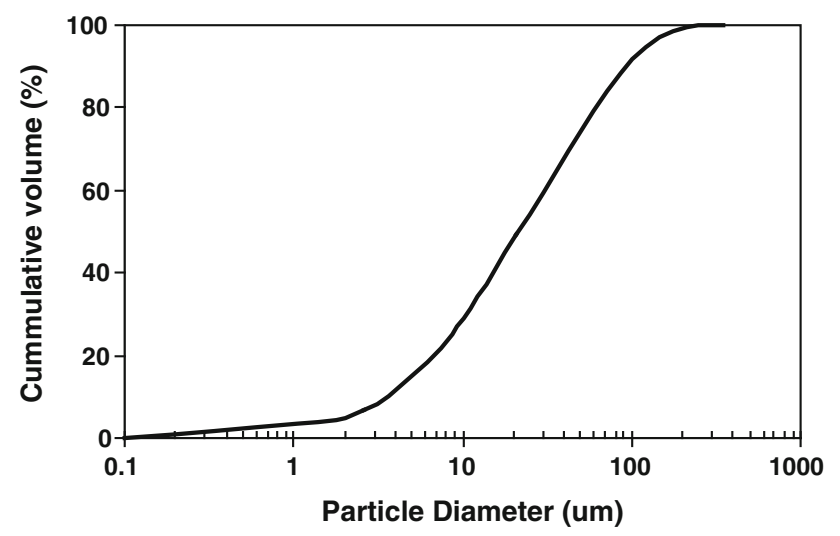

Fig. 1 Particle size distribution of the fly ash

AAF were synthesized by mixing fly ash with activating solutions. For mechanical tests, specimens were cast in $40 \times 40 \times 160 \mathrm{~mm}^{3}$ molds. Samples for MIP and XRD tests were prepared in small plastic bottles. After casting, all the samples were vibrated for 2 min to remove the entrapped air. The samples were then sealed by plastic foil and cured in an oven at $40{ }^{\circ} \mathrm{C}$ before tests. All the tests were performed at the curing ages of 7 and 28 days, respectively, at room temperature.

Methods

\section{Mechanical strength}

At each curing age (7 and 28 days), the mechanical properties, including flexural strength and compressive strength, were measured by standard three-point bending test on $40 \times 40 \times 160 \mathrm{~mm}^{3}$ prisms and standard compression test on $40 \times 40 \times 40 \mathrm{~mm}^{3}$ cubes. There were at least three replicates for each group.

\section{MIP}

At each curing age, samples were broken into $1-2 \mathrm{~cm}^{3}$ pieces by hammer. The crushed samples were then frozen by immersed in liquid nitrogen and placed in a vacuum freeze-dryer for at least 2 weeks to remove the pore water. This process was reported [27] having smaller damage on the pore structure compared to the oven dry method. MIP tests were conducted by using Micrometritics Poresizer 9500 , with the pressure running from 0.0036 to $210 \mathrm{MPa}$. The surface tension of mercury was $485 \times 10^{-3} \mathrm{~N} / \mathrm{m}$ and the contact angle was $132^{\circ}$ [28]. According to Washburn equation [29], the pore size ranging from 350 to $0.007 \mu \mathrm{m}$ can be detected. The total porosity and differential pore size distribution could be deduced from the MIP tests.

\section{ESEM}

A Philips-XL30-environmental scanning electron microscope was applied to obtain the morphology of fly ashbased geopolymers. Backs scattered electron (BSE) detector was used to acquire the images. The samples were first subjected to epoxy impregnation and further grinded and polished. Detail procedure for sample preparation was referred to [27]. During the acquisition of images, the acceleration voltage was $20 \mathrm{kV}$ and the water vapor pressure was 1.0 Torr. The magnification was $500 \times$ and the physical size of the region in each image was $248 \mu \mathrm{m}$ in length and $188 \mu \mathrm{m}$ in width.

\section{$X R D$}

The XRD analysis was performed by using a Philips PW 1830 powder diffractometer running from 5 to $70^{\circ}$. Energy source was Co $K_{\alpha}(1.789 \AA)$ and the tube settings were $45 \mathrm{kV}$ and $30 \mathrm{~mA}$.

\section{Isothermal calorimetry}

Before the tests, the calorimeter (Thermometric ATM Air 314) was calibrated at $40{ }^{\circ} \mathrm{C}$ and the materials (fly ash and alkali solutions) were stored at $40{ }^{\circ} \mathrm{C}$ for $24 \mathrm{~h}$. Fly ash was first mixed with alkali solution for $1 \mathrm{~min}$; afterward about $10 \mathrm{~g}$ paste was carefully poured into glass ampoules and transferred into the calorimeter channel running at $40{ }^{\circ} \mathrm{C}$. The whole procedure was finished within $3 \mathrm{~min}$. For this reason, the first heat peak, which occurs immediately after mixing, was not recorded. The heat flow was recorded and the cumulative heat was counted up to $168 \mathrm{~h}$ (7 days).

\section{Results and discussion}

Development of compressive and flexural strength

Figures 3 and 4 show the influence of $\mathrm{SiO}_{2}$ and $\mathrm{Na}_{2} \mathrm{O}$ content on the compressive and flexural strength of AAF at the curing age of 7 and 28 days, respectively. With more 


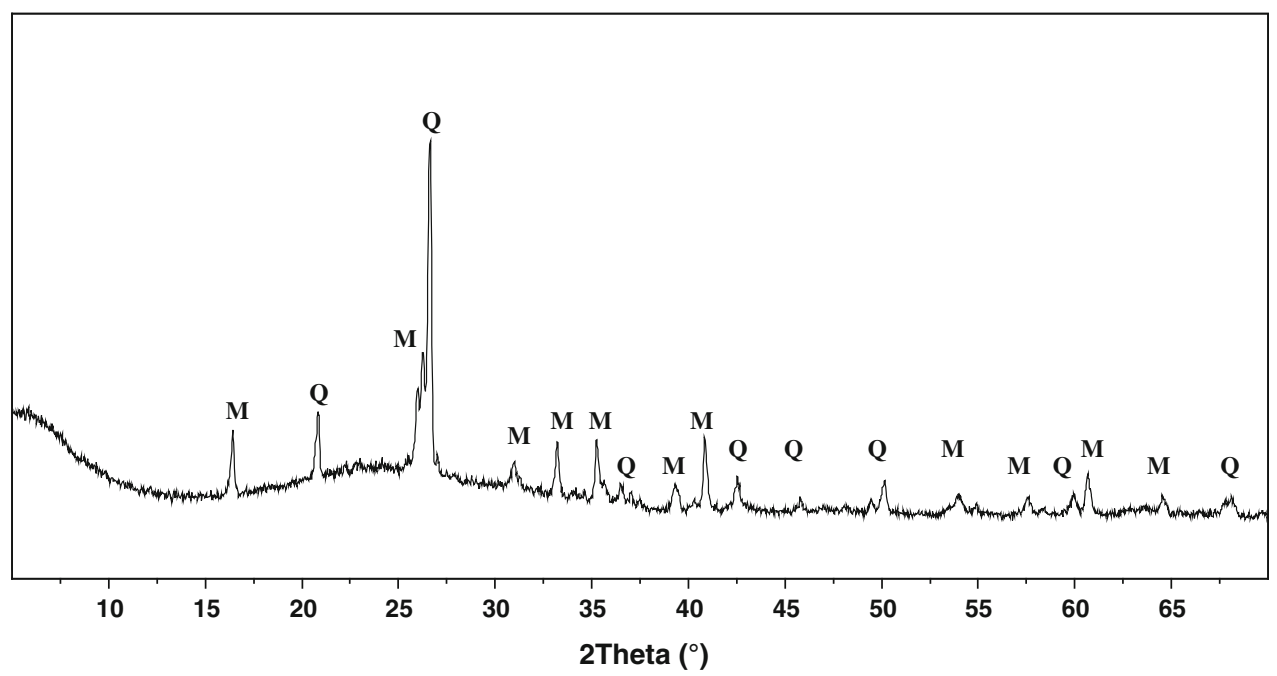

Fig. 2 X-ray diffraction analysis of the fly ash, $Q$ quartz $\left(\mathrm{SiO}_{2}, \mathrm{PDF} \#\right.$ 85-0457); $M$ mullite $\left(\mathrm{Al}_{4.8} \mathrm{O}_{9.54} \mathrm{Si}_{1.2}, \mathrm{PDF} \#\right.$ 84-1205)

Table 3 Composition of alkali solutions mixing with $1 \mathrm{~kg}$ fly ash

\begin{tabular}{lll}
\hline Sample $\left(\mathrm{SiO}_{2}-\mathrm{Na}_{2} \mathrm{O}\right)$ & $\mathrm{SiO}_{2}(\mathrm{~mol})(\mathrm{wt} \%)^{\mathrm{a}}$ & $\mathrm{Na}_{2} \mathrm{O}(\mathrm{mol})(\mathrm{wt} \%)^{\mathrm{a}}$ \\
\hline $1.5-1.5$ & $1.5(9.0)$ & $1.5(9.3)$ \\
$1.3-1.5$ & $1.3(7.8)$ & $1.5(9.3)$ \\
$1-1.5$ & $1.0(6.0)$ & $1.5(9.3)$ \\
$0.5-1.5$ & $0.5(3.0)$ & $1.5(9.3)$ \\
$0-1.5$ & 0.0 & $1.5(9.3)$ \\
$1.5-1.3$ & $1.5(9.0)$ & $1.3(8.0)$ \\
$1.3-1.3$ & $1.3(7.8)$ & $1.3(8.0)$ \\
$1-1.3$ & $1.0(6.0)$ & $1.3(8.0)$ \\
$1.5-1$ & $1.5(9.0)$ & $1.0(6.2)$ \\
$1.3-1$ & $1.3(7.8)$ & $1.0(6.2)$ \\
$1-1$ & $1.0(6.0)$ & $1.0(6.2)$ \\
$0.5-1$ & $0.5(3.0)$ & $1.0(6.2)$ \\
$0-1$ & 0.0 & $1.0(6.2)$ \\
\hline
\end{tabular}

${ }^{\mathrm{a}}$ Weight ratio with respect to fly ash content

$\mathrm{Na}_{2} \mathrm{O}$ content in the activator, the compressive strength of $\mathrm{AAF}$ increased at both curing ages. Bakharev [21] also found higher strength when $\mathrm{Na}_{2} \mathrm{O}$ addition increased from 2 to $8 \mathrm{wt} \%$ of fly ash. However, further increase in alkali content (till $14.90 \mathrm{wt} \%$ of fly ash) was reported to result in a decrease of compressive strength [23]. In this study, higher alkali content ( $2 \mathrm{~mol} / \mathrm{kg}$ fly ash) was not used due to the precipitation of alkali solutions when silica was present. Increasing the amount of $\mathrm{SiO}_{2}$ only led to a higher compressive strength at the age of 7 days (Fig. 3). However, at 28 days curing age, the highest strength appeared at different silica content with respect to the $\mathrm{Na}_{2} \mathrm{O}$ amount. For example, when the $\mathrm{Na}_{2} \mathrm{O}$ content was $1.0,1.3,1.5 \mathrm{~mol} / \mathrm{kg}$ fly ash, the highest compressive strength was obtained with the silica content of $1.0,1.3$, and $1.3 \mathrm{~mol} / \mathrm{kg}$ fly ash, respectively (Fig. 4). Therefore, it could be stated that in

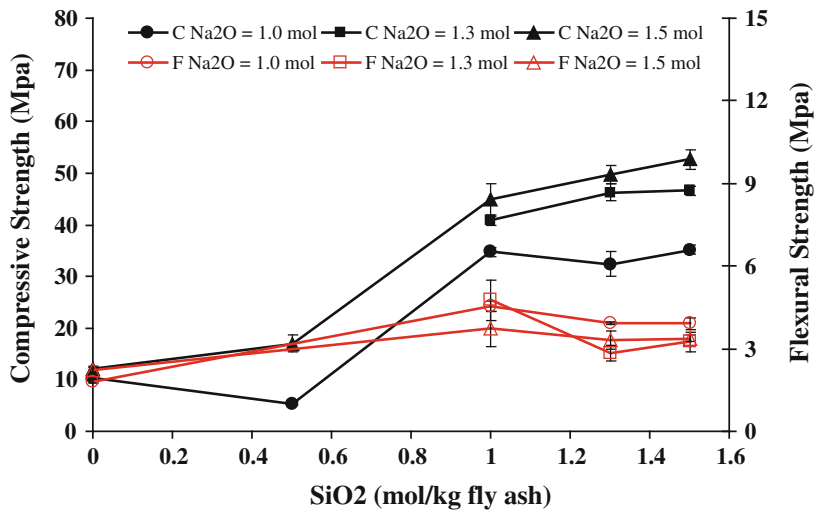

Fig. 3 Influence of $\mathrm{SiO}_{2}$ and $\mathrm{Na}_{2} \mathrm{O}$ content on compressive $(C)$ and flexural strength $(F)$ at 7 days, $40{ }^{\circ} \mathrm{C}$, water/FA ratio $=0.35$

the presence of silica in activator, higher amount of alkali $\left(\mathrm{Na}_{2} \mathrm{O}\right)$ was beneficial for the compressive strength development. However, there was an optimal content of soluble silica $\left(\mathrm{SiO}_{2}\right)$ with respect to the $\mathrm{Na}_{2} \mathrm{O}$ content. The existence of the optimal silica content in activator agrees well with the findings by Fernández-Jiménez et al. [20] and Duxson et al. [30] in previous studies.

For flexural strength, a different trend was observed compared to the compressive strength. When the $\mathrm{SiO}_{2}$ content varied from 1.0 to $1.5 \mathrm{~mol} / \mathrm{kg}$ of fly ash, more $\mathrm{SiO}_{2}$ and $\mathrm{Na}_{2} \mathrm{O}$ content led to a decrease of flexural strength both at 7 and 28 days curing ages. The reduction of flexural strength is thought to relate to the structural ordering of the reaction products of AAF. One plausible reason is that increasing the silica and sodium contents in activating solution may resulted in reduced level of long-range structural ordering products [31]. The less chemically connected products lead to the decrease of flexural strength. 


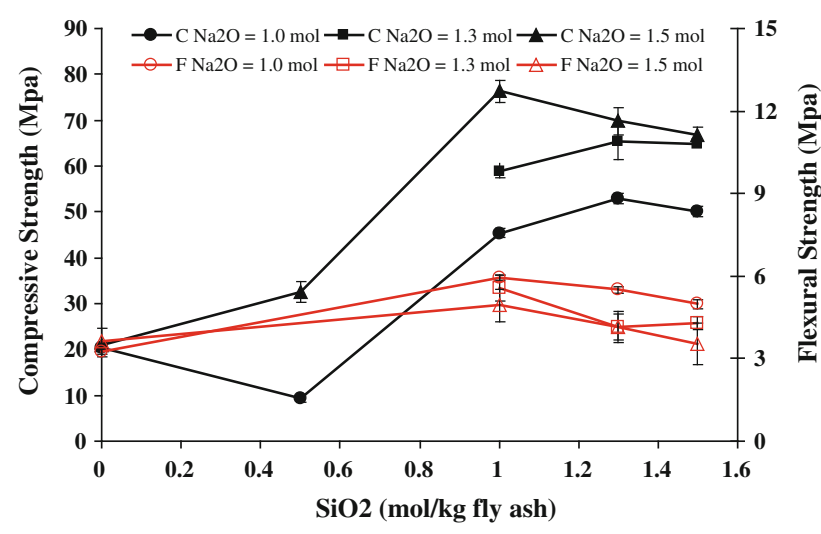

Fig. 4 Influence of $\mathrm{SiO}_{2}$ and $\mathrm{Na}_{2} \mathrm{O}$ content on compressive $(C)$ and flexural strength $(F)$ at 28 days, $40{ }^{\circ} \mathrm{C}$, water/FA ratio $=0.35$

Rate of reaction by conduction calorimetry

The heat evolution and cumulative heat of the AAF (at $40{ }^{\circ} \mathrm{C}$ ) with different contents of activator during the first $168 \mathrm{~h}$ is presented in Fig. 5. In general, the released heat of AAF was considerably lower compared to ordinary Portland cement, which was reported to have a total heat release around $350 \mathrm{~J} / \mathrm{g}$ after 7 days [32]. When the alkali content was fixed (three gray lines or three black lines in Fig. 5), a higher $\mathrm{SiO}_{2}$ content led to a lower heat release, whereas an increase of alkali content resulted in a higher total heat release (line $1.5-1.5$ and $1.5-1$, or $1.3-1.5$ and $1.3-1$, or $1-1.5$ and $1-1$ in Fig. 5). The result revealed that the addition of $\mathrm{SiO}_{2}$ retarded the reaction, while $\mathrm{Na}_{2} \mathrm{O}$ was favorable to the reaction. By using acid attack method, Criado et al. [25] also found lower reaction degree with increased silica content of AAF.

\section{Microstructure development of AAF by MIP and ESEM}

MIP is widely used to measure both the porosity and pore size distribution of cement-based materials [33, 34]. However, the application of MIP on AAF was rarely reported. Though it was argued that MIP method cannot reflect the true pore size distribution of porous materials due to the different pore shapes and "ink-bottle" effect [35], the comparison between the MIP results itself could still provide valuable information on the pore structure development of AAF.

For ordinary Portland cement, in general, there are two peaks in the differential curves, corresponding to two pore systems: the gel pores of cement paste are formed by the $\mathrm{C}-\mathrm{S}-\mathrm{H}$ gels, with pore size diameter ranging from $0.5 \mathrm{~nm}$ to $0.01 \mu \mathrm{m}$ [36]; the capillary pores refers to the spaces left by the water that do not filled with reaction products, with pore size range of $0.01-10 \mu \mathrm{m}[36]$.

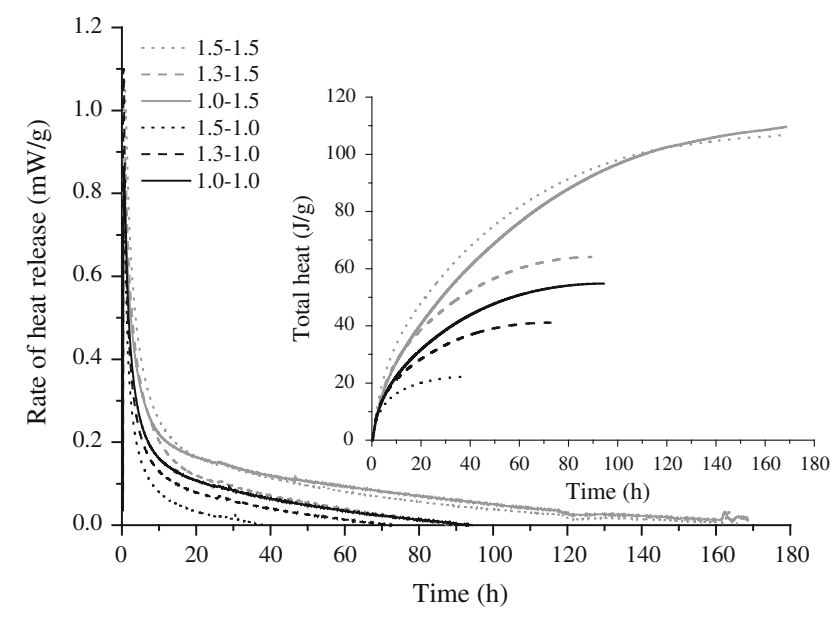

Fig. 5 Heat evolution and cumulative heat of alkali-activated fly ash with different sodium silicate solutions, temperature $40{ }^{\circ} \mathrm{C}$

For the differential curves of AAF (Figs. 6, 7), despite two peaks were also detected for most of the samples, corresponding to two pore systems in AAF, the formation of the pores was very different compared to Portland cement. The "gel pores" of AAF, with the diameter in the range of several nanometers to $0.02 \mu \mathrm{m}$ are formed by the aluminosilicate gels. Unlike the formation of $\mathrm{C}-\mathrm{S}-\mathrm{H}$ gels in Portland cement paste, which grow around the surface of cement particles [27], the gels of fly ash activated with high silica content were observed evenly distributed in the matrix (Fig. 8c-f). As for the "capillary pores" in AAF, the capillary pores that are typical in Portland cement were not observed. On the other hand, a number of pores were formed by the dissolved fly ash particles (Fig. $8 \mathrm{c}-\mathrm{f}$ ). These pores were in the range of several microns to larger than 10 microns in diameter, constituting the "capillary pore" system as shown in Fig. 6b, d, f. Based on the information discussed above, the simplified processes of microstructure formation in $\mathrm{AAF}$ and cement paste are illustrated in Fig. 9. As demonstrated in Fig. 9a, because the capillary pores of AAF are blocked by the homogeneous gels, they can only be accessed through the gel pores when mercury is intruded in the matrix, which would cause a significant "ink-bottle" effect. Therefore, the capillary pores in AAF measured by MIP (Figs. 6, 7) were in the range of 0.1-1 microns, about one order of magnitude smaller than the real diameter observed from ESEM images (Fig. 8). As for specimen with no or very low soluble silica content $(0-1.5$ and $0.5-1.5$ ), the formation of gel phase was limited and only grew around the un-reacted fly ash particles, typical capillary pores as in Portland cement were observed in Fig. $8 \mathrm{a}, \mathrm{b}$ resulting in the only peak of capillary pore in the differential curve in Fig. $6 \mathrm{~b}$ for specimen 0.5-1.5. The poorly reacted fly ash and the high porosity of the matrix led to the low mechanical properties of AAF (Fig. 4). 

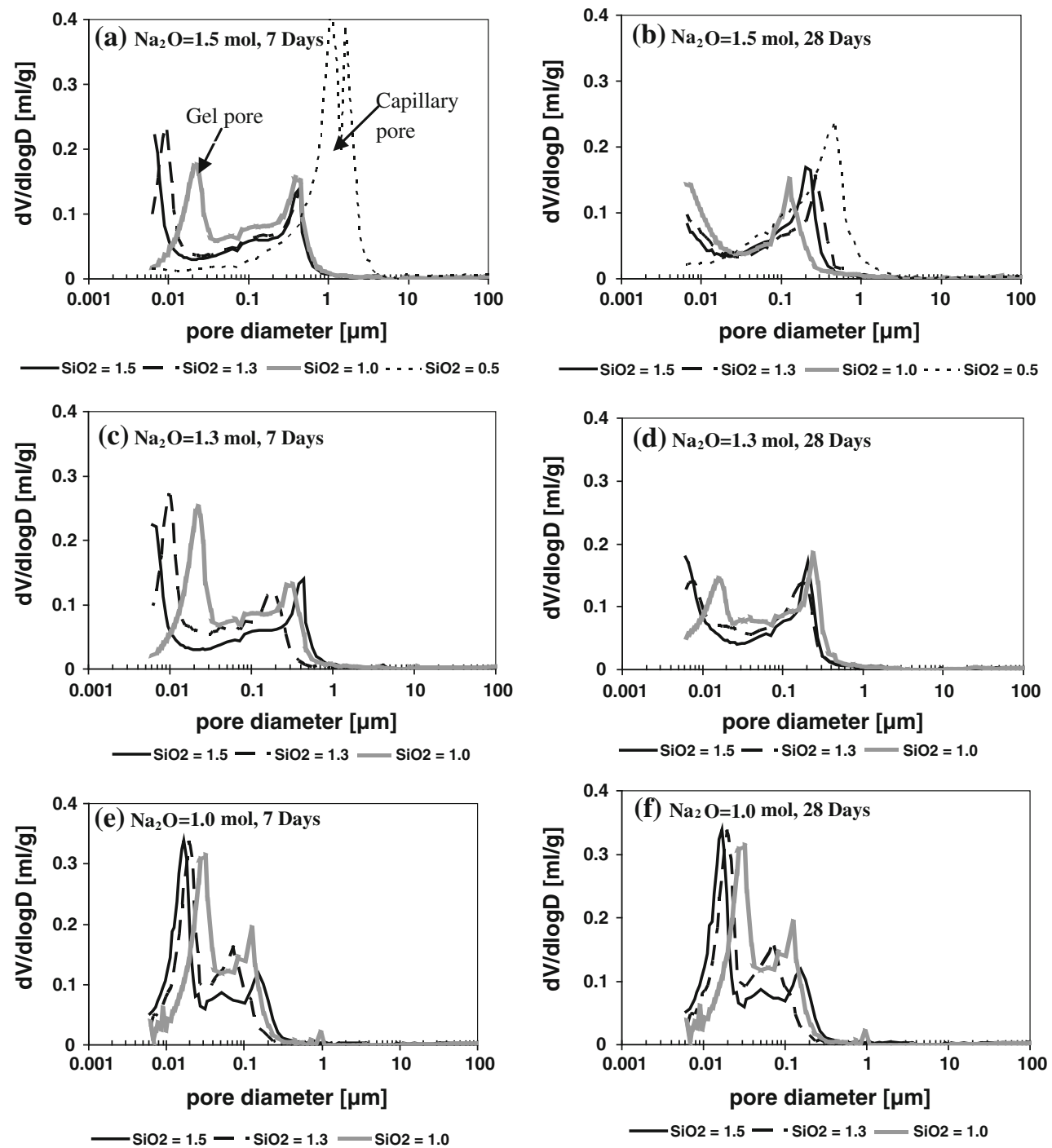

Fig. 6 Differential curves of pore size distribution of AAF activated with different content of $\mathrm{SiO}_{2}$ derived by MIP (Na $\mathrm{Na}_{2} \mathrm{O}$ was kept constant)

Similar findings on the pore structure of AAF were also reported by Lloyd et al. [37] using wood's metal intrusion method and scanning electron microscopy [38, 39].

As illustrated from Table 4, the total porosity obtained from MIP decreased as silica and alkali content increased both at 7 and 28 days. Increasing the $\mathrm{SiO}_{2}$ or $\mathrm{Na}_{2} \mathrm{O}$ content from 1.0 to $1.5 \mathrm{~mol}$, the critical pore diameter (the diameter corresponding to the peak in differential curve) of gel pores of AAF shifted to a lower pore diameter (Table 4; Figs. 6,7), indicating a denser pore structure formed.

The relationship between reaction degree, microstructure, and strength

According to Glukhovsky [40], the alkali activation process of aluminosilicate materials was constituted of three stages: destruction-coagulation, coagulation-condensation, and condensation-crystallization. Other authors [31] extended Glukhovsky's theory and proposed a more detailed description of the model for the alkali activation process. Five steps were involved in the reaction process: namely dissolution, speciation equilibrium, gelation, reorganization and polymerization and hardening. In general, in the initial stage, when alkali solution comes in contact with fly ash particles, it dissolves the vitreous phase in fly ash, releasing monomers aluminates and silicates species into the medium [19]. These small ionic species contact with each other, forming a coagulated structure, giving rise to a three-dimensional aluminosilicate gel, also called zeolite precursors [11]. This gel is responsible for the cementitious properties of alkali activated material.

The addition of alkali cations into the activating solution is considered to have two effects: first, it increases the $\mathrm{pH}$ in the solution; high amount of $\mathrm{OH}^{-}$ions helps to sever the $\mathrm{Si}-\mathrm{O}-\mathrm{Si}$ and $\mathrm{Si}-\mathrm{O}-\mathrm{Al}$ bonds of the reactive fly ash into small silicon and aluminum species [19]; second, the alkali 
Fig. 7 Differential curves of pore size distribution of AAF activated with different content of $\mathrm{Na}_{2} \mathrm{O}$ derived by $\mathrm{MIP}\left(\mathrm{SiO}_{2}\right.$ was kept constant)
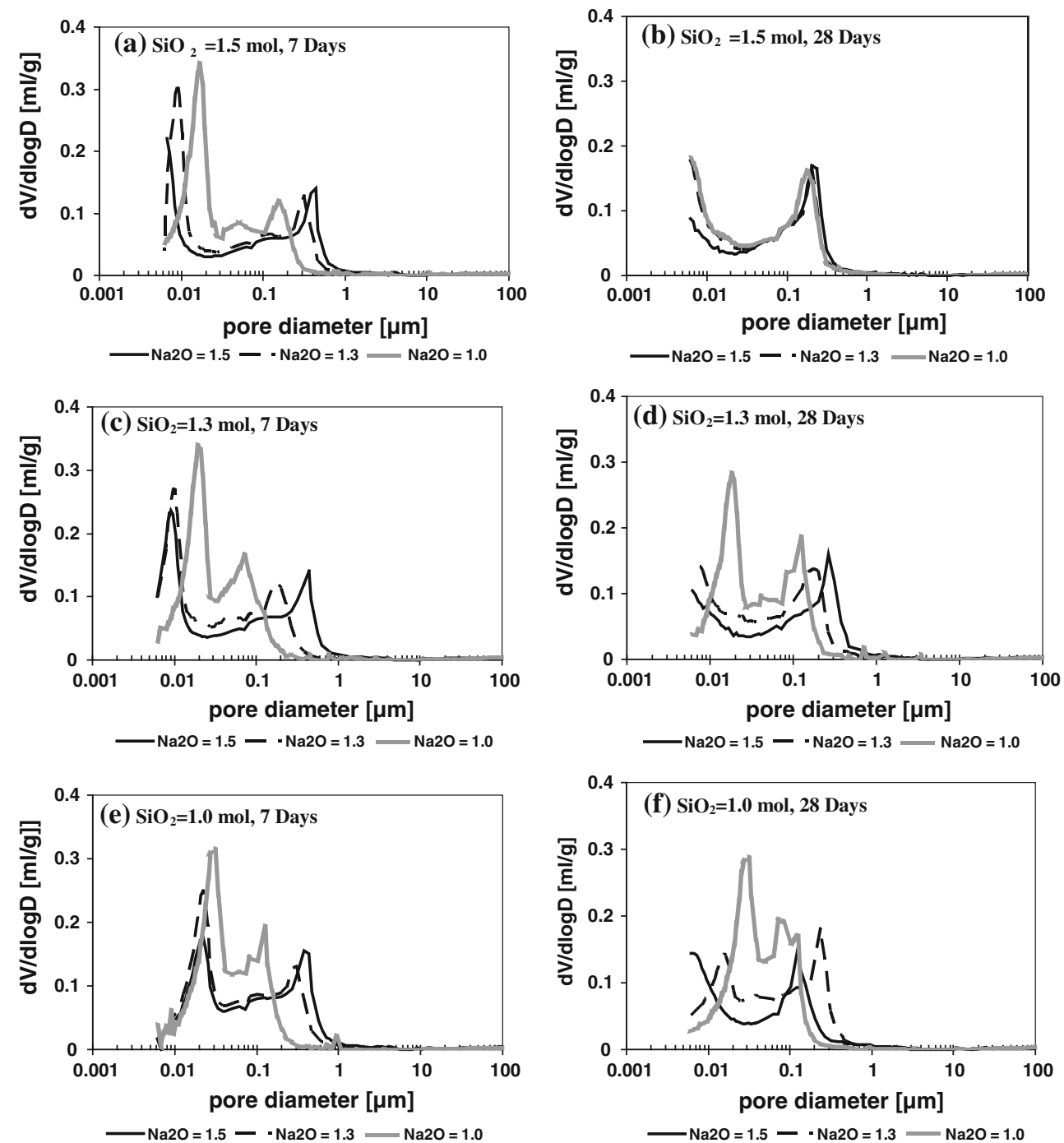

cation balances the electric charge in the tetrahedral $\mathrm{Si}$ and Al structure [25]. Therefore, in this study, when more sodium oxide presents in the activator, specimens exhibit a higher compressive strength, higher extent of reaction, lower porosity, and finer pore size distribution. Higher alkali content dissolves more fly ash particles into the medium, ready for the next steps of reactions (gelation and polymerization).

Unlike the effect of alkali, the addition of soluble silica influences the properties of AAF in two ways. On one hand, the soluble silica species in activating solution cause a lower total heat release (Fig. 5), corresponding to a lower extent of reaction. It is reported [41] that with more silica amount, the fraction of monomer and dimer form of silicate species in the alkaline solutions decreased, while the trimer unit content grew. The higher degree of silicate ion polymerization in the medium retards the further dissolution of fly ash particles, leading to a lower reaction degree. On the other hand, these silicate species react with the aluminum species dissolved from the fly ash particles to form the aluminosilicate gels. Unlike the gels formed without soluble silica (Fig. 8a), which mainly precipitate on the surface of fly ash particles, they were evenly distributed in the matrix, forming a more homogeneous and denser microstructure (Fig. 8c-f). Therefore, lower total porosity and finer gel pore system were observed for specimens with more $\mathrm{SiO}_{2}$ content at early age (Table 4). This is the reason why the specimens with higher $\mathrm{SiO}_{2}$ content exhibit a lower degree of reaction but developed a lower total porosity. The compressive strength, which was closely related to its reaction degree and microstructure, as a result, increases with higher $\mathrm{SiO}_{2}$ content in early age (Fig. 3), and exhibited an optimal value at different silica content with respect to the alkali content.

In this study, a series of activating solutions, with the $\mathrm{SiO}_{2}$ content varied from 0 to $9 \%$ and $\mathrm{Na}_{2} \mathrm{O}$ between 6.2 and $9.3 \%$ (by the weight of fly ash), were applied to activated fly ash. The result demonstrated that the highest 

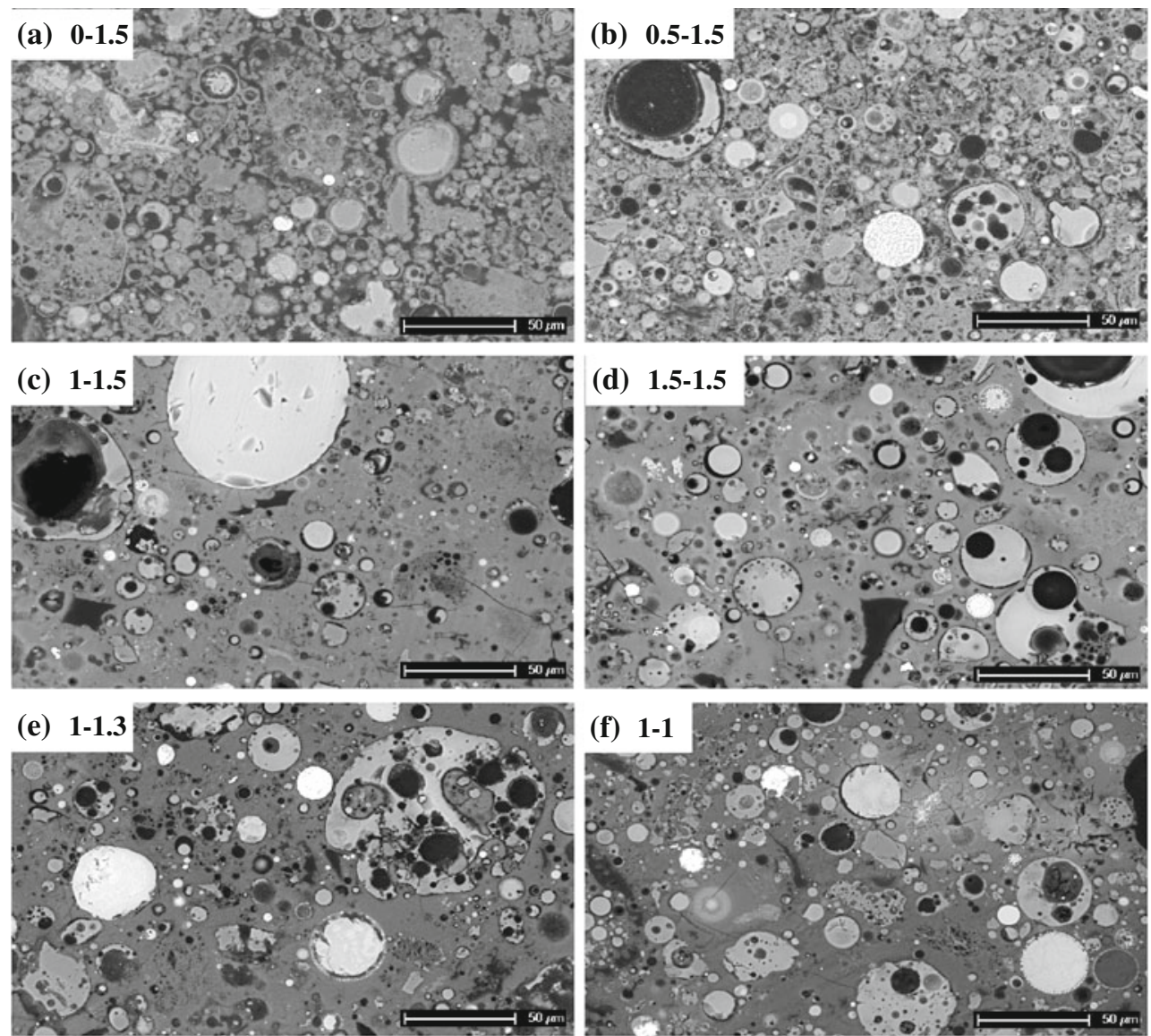

Fig. 8 BSE images of AAF activated with various sodium silicate at 28 days $\left(40{ }^{\circ} \mathrm{C}\right)(\times 500)$
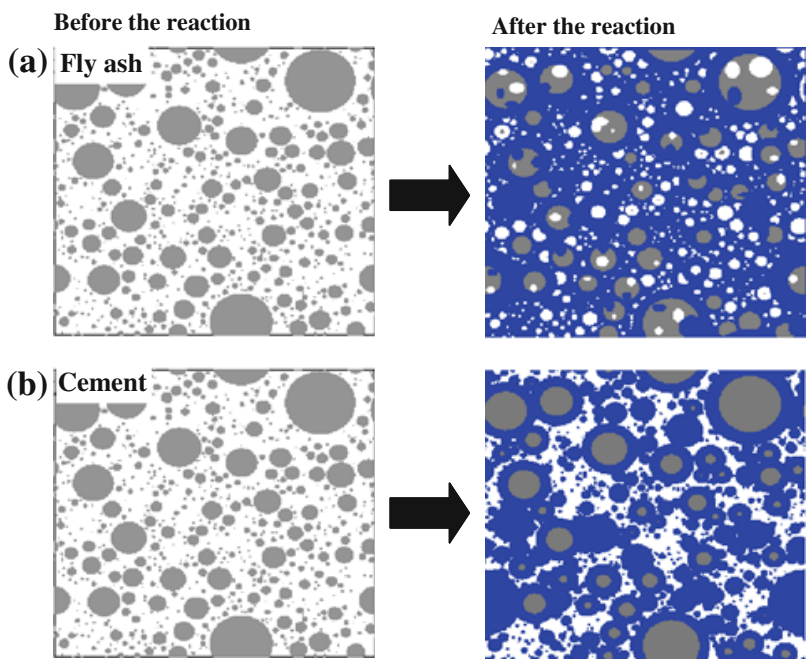

$\square$ un-reacted particles

reaction products (gels) $\square$ pores (capillary)

Fig. 9 Formation of the microstructure (simplified) in different systems: a AAF activated with high silica content in this study; b cement-based materials or AAF activated with no or low silica contents

strength was obtained when $\mathrm{SiO}_{2}$ content was $6 \%(1.0 \mathrm{~mol} /$ $\mathrm{kg}$ fly ash) and $\mathrm{Na}_{2} \mathrm{O}$ content at $9.3 \%$ (1.5 mol/ $/ \mathrm{kg}$ fly ash). Though the optimal value would vary substantially with the chemical composition and reactivity of fly ash (Table 1), similar amount of activator was reported in previous studies, where $7 \mathrm{wt} \%$ of $\mathrm{SiO}_{2}$ and $7 \mathrm{wt} \% \mathrm{Na}_{2} \mathrm{O}$ (weight ratio of fly ash) were used in the study by Lloyd et al. [37], and 7.5 and $8 \mathrm{wt} \% \mathrm{Na}_{2} \mathrm{O}$ (weight ratio of fly ash) were reported by Škvára et al. [24] and Bakharev [21], respectively.

Phase development by X-ray diffraction and its relationship to strength

The mineralogy of AAF under different conditions (activator, temperature, or curing condition) was widely reported [42, 43]. Figures 10 and 11 show that the reaction products of AAF were predominantly amorphous compound, regardless of the alkali solutions. Quartz and mullite are the main crystalline phases remained in the unreacted fly ash. The vitreous phase in original fly ash exhibited a bump between 20 and $25^{\circ} 2 \theta$. After the alkali activation, the bump shifted to a higher degree in the range of $27-30^{\circ} 2 \theta$.

Different types of zeolite crystalline phases were observed in Fig. 10 for the specimen with medium amount 
Table 4 Total porosity and critical pore diameter of AAF at different ages derived by MIP

\begin{tabular}{lllll}
\hline Sample & $\begin{array}{l}\text { Total } \\
\text { porosity at } \\
7 \text { days }(\%)\end{array}$ & $\begin{array}{l}\text { Total } \\
\text { porosity at } \\
28 \text { days } \\
(\%)\end{array}$ & $\begin{array}{l}\text { Critical pore } \\
\text { diameter at } \\
7 \text { days }(\mu \mathrm{m})\end{array}$ & $\begin{array}{l}\text { Critical pore } \\
\text { diameter at } \\
28 \text { days }(\mu \mathrm{m})\end{array}$ \\
\hline $1.5-1.5$ & 22.40 & 20.94 & $<0.007$ & $<0.007$ \\
$1.3-1.5$ & 27.37 & 21.55 & 0.009 & $<0.007$ \\
$1-1.5$ & 27.95 & 20.67 & 0.020 & $<0.007$ \\
$0.5-1.5$ & 37.71 & 30.93 & No & No \\
$1.5-1.3$ & 26.29 & 22.35 & 0.007 & $<0.007$ \\
$1.3-1.3$ & 27.14 & 25.29 & 0.010 & $<0.007$ \\
$1-1.3$ & 29.65 & 28.13 & 0.022 & 0.017 \\
$1.5-1$ & 28.87 & 23.29 & 0.016 & $<0.007$ \\
$1.3-1$ & 26.73 & 25.80 & 0.020 & 0.018 \\
$1-1$ & 31.53 & 30.67 & 0.030 & 0.030 \\
\hline
\end{tabular}

of soluble silica (faujasite- $\mathrm{Na}$ for $0.5-1.5$ and $1-1.5$ ) and without silica (hydroxysodalite for $0-1.5$ ) presented in activating solution. However, no clear crystalline was detected from the XRD pattern when the silica content further increased (mixture 1.3-1.5 and 1.5-1.5). These results are consistent with the findings by other authors [23, 25]. From the observations, it is assumed that the higher degree of silica polymerization in solutions with higher soluble silica content requires more energy for transferring the aluminosilicate gel into well-organized crystalline [25].
The sodium oxide content also had a prominent effect on the mineralogy. When the silica content was $1.0 \mathrm{~mol}$, an increase of the alkali content resulted in the formation of zeolite phase faujasite-Na (Fig. 11, pattern 1-1.5); while the silica content was kept constant at $1.5 \mathrm{~mol} / \mathrm{kg}$ fly ash, new crystalline phase was not detected in high sodium oxide samples. Similar result was also reported by Lloyd [19] in the aging of AAF.

One of the most important reasons to study the mineralogy of AAF is to evaluate the stability of AAF in a long timescale [19]. In previous studies of alkali activated metakaolin [19, 44], which has similar composition of raw material and reaction products as AAF, the loss of strength was detected accompanying with the formation of zeolite crystalline phases. In AAF, similar results were also reported [25], indicating that a higher content of zeolites in AAF prevented the mechanical strength development. However, it was found in this study that specimen 1-1.5, which had crystalline zeolite formed at 28 days, exhibited the highest compressive strength. In the aging test of AAF by Lloyd et al. [19], the drop of compressive strength was also not observed with the formation of zeolite crystalline phases. As for the other two mixtures, specimens 0-1.5 and 0.5-1.5, which also had zeolite crystalline phases but showed lower mechanical strength, it is assumed that the lower strength is mainly related to the porous and loosen microstructure formed in the matrix (Figs. 6a, 8a, b), rather than the zeolite.
Fig. 10 XRD of alkaliactivated fly ash with various $\mathrm{SiO}_{2}$ content at 28 days $40{ }^{\circ} \mathrm{C}$; $Q$ quartz $\left(\mathrm{SiO}_{2}, \mathrm{PDF} \#\right.$ 85-0457), $M$ mullite $\left(\mathrm{Al}_{4.8} \mathrm{O}_{9.54} \mathrm{Si}_{1.2}, \mathrm{PDF}\right.$ 84-1205), $H$ hydroxydodalite $\left(\mathrm{Na}_{4} \mathrm{Al}_{3} \mathrm{Si}_{3} \mathrm{O}_{12}(\mathrm{OH})\right.$, PDF\# 11-0401), $F$ faujasite $\left(\mathrm{Na}_{1.84} \mathrm{Al}_{2} \mathrm{Si}_{4} \mathrm{O}_{11.92} \cdot 7 \mathrm{H}_{2} \mathrm{O}\right.$, PDF\# 38-0238)

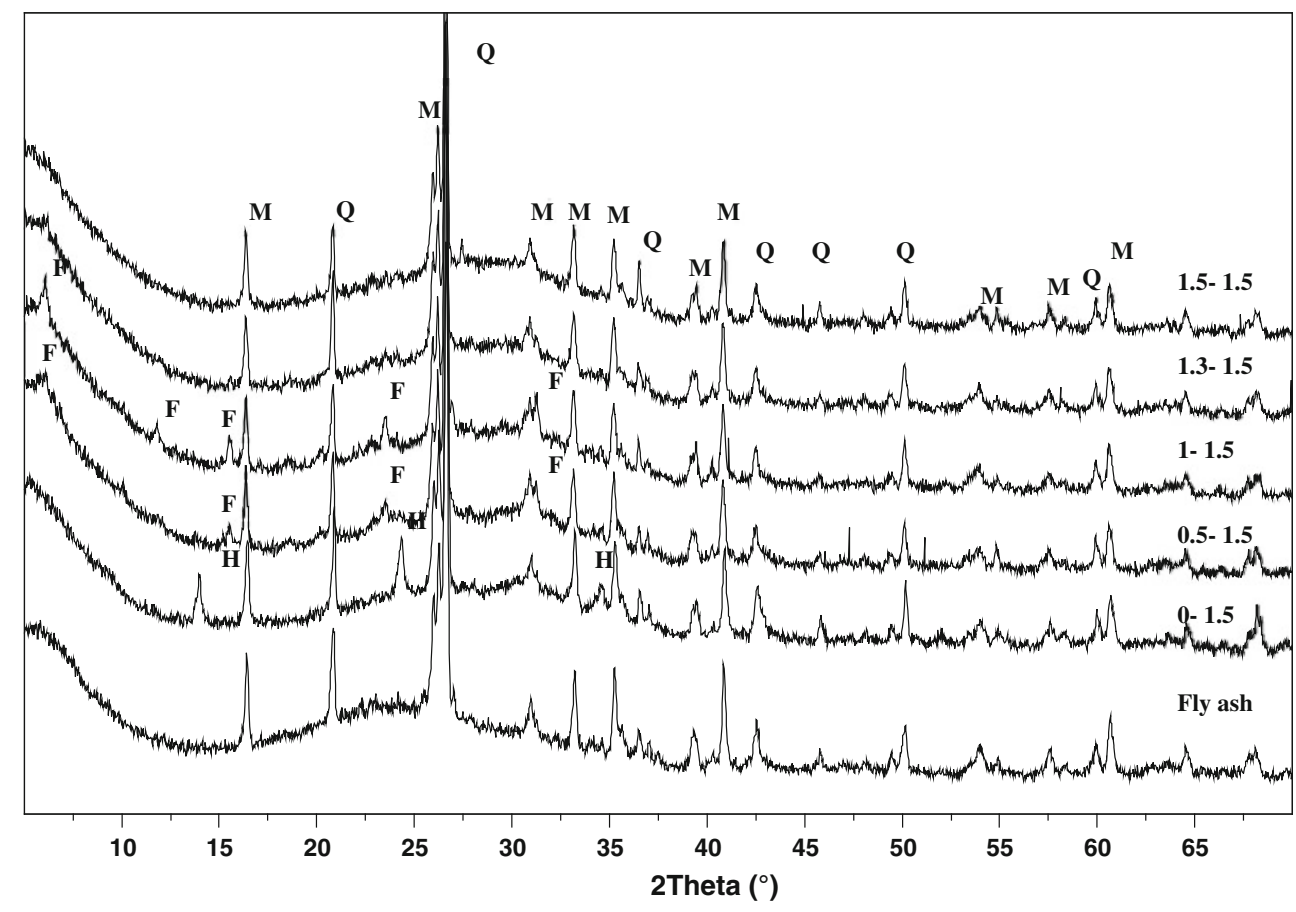




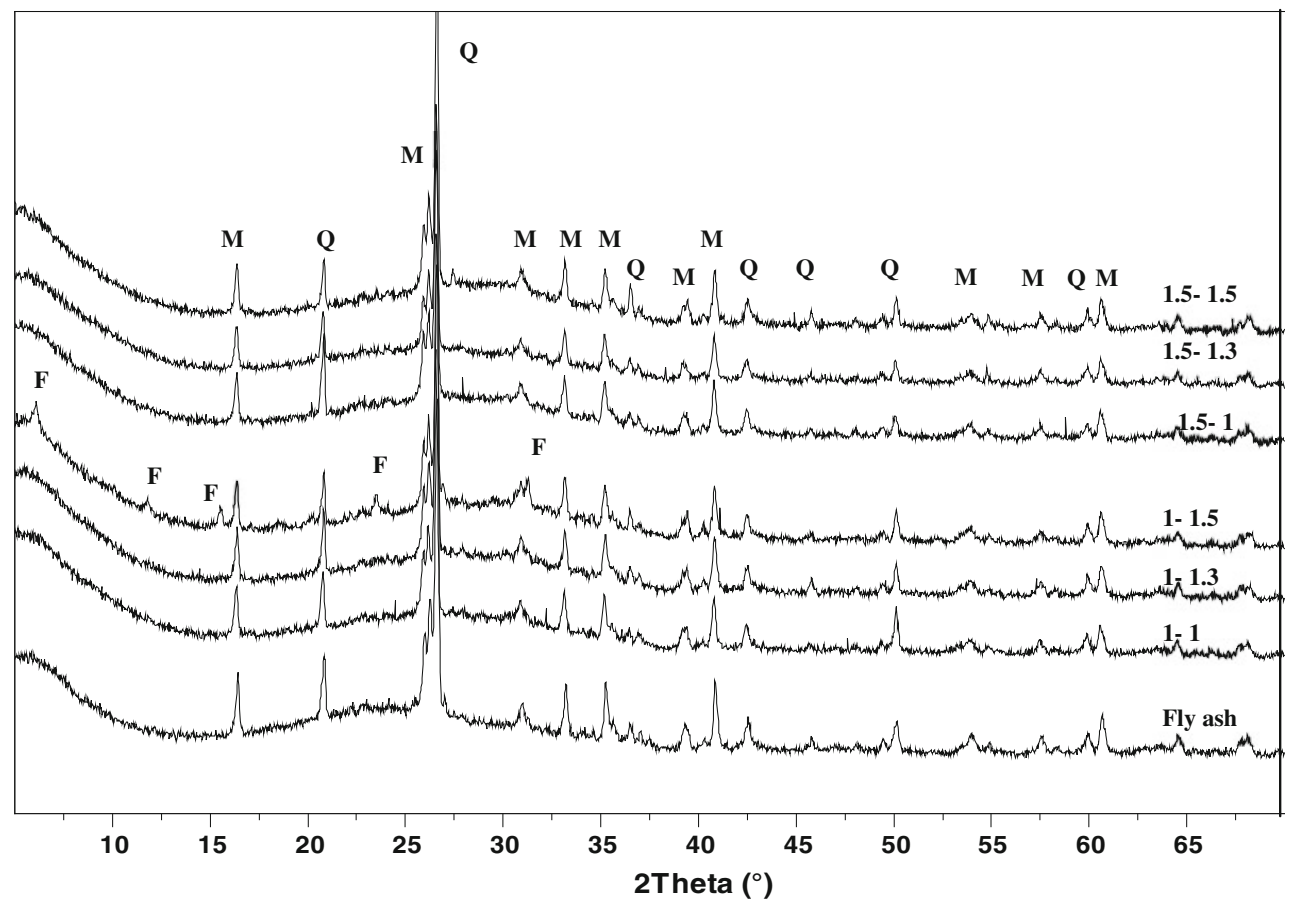

Fig. $11 \mathrm{XRD}$ of alkali-activated fly ash with various $\mathrm{Na}_{2} \mathrm{O}$ at 28 days $40{ }^{\circ} \mathrm{C} ; Q$ quartz $\left(\mathrm{SiO}_{2}, \mathrm{PDF} \# 85-0457\right), M$ mullite $\left(\mathrm{Al}_{4.8} \mathrm{O}_{9.54} \mathrm{Si}_{1.2}, \mathrm{PDF} \#\right.$ 84-1205), $F$ faujasite $\left(\mathrm{Na}_{1.84} \mathrm{Al}_{2} \mathrm{Si}_{4} \mathrm{O}_{11.92} \bullet 7 \mathrm{H}_{2} \mathrm{O}\right.$, PDF\# 38-0238)

\section{Conclusion}

Based on the experimental results, the following conclusions can be drawn from this study:

(1) Both the amounts of $\mathrm{SiO}_{2}$ and $\mathrm{Na}_{2} \mathrm{O}$ in activating solutions have a prominent effect on the mechanical properties, reaction rate and microstructure development of AAF: more sodium oxide content leads to a higher extent of reaction and denser matrix, corresponding to a higher compressive strength; the addition of silica in the alkaline solution retards the extent of reaction, while improves the microstructure in the matrix. Therefore, a higher compressive strength was obtained in the early age with increasing $\mathrm{SiO}_{2}$ content, but exhibited the highest value with silica content between 1.0 and $1.3 \mathrm{~mol} / \mathrm{kg}$ fly ash with respect to specific alkali content. These results correlate well with the previously findings of the activating solutions on AAF.

(2) The pore structure of AAF is very different from that of cement-based material: the aluminosilicate gels are uniformly distributed in the matrix; capillary pores are the space left by dissolved fly ash particles and appear to be isolated by the aluminosilicate gels.

(3) Different types of zeolite crystalline phases are detected when the silica content was low $(0,0.5$, and $1.0 \mathrm{~mol}$ ) in activating solution. More silica content suppresses the formation of zeolite crystalline. When the silica content is low, zeolite crystalline is detected with increasing $\mathrm{Na}_{2} \mathrm{O}$ amount. The transition of aluminosilicate gel to crystalline did not lead to strength loss in AAF.

(4) Based on the results of strength, microstructure development and total heat release, the optimal content of $\mathrm{SiO}_{2}$ and $\mathrm{Na}_{2} \mathrm{O}$ in activating solution to activated fly ash is determined as 1.0 and $1.5 \mathrm{~mol} / \mathrm{kg}$ fly ash, respectively.

Acknowledgement The first author of this work was supported by the China Scholarship Council project "National Study-abroad Project for Postgraduates of Key Constructed High Level Universities in China“.

Open Access This article is distributed under the terms of the Creative Commons Attribution License which permits any use, distribution, and reproduction in any medium, provided the original author(s) and the source are credited.

\section{References}

1. Allwood JM, Cullen JM, Milford RL (2010) Environ Sci Technol 44:1888

2. Worrell E, Price L, Martin N, Hendriks C, Meida LO (2001) Annu Rev Energy Environ 26:303

3. Davidovits J (1989) J Therm Anal Calorim 35:429

4. Lam L, Wong Y, Poon C (2000) Cement Concrete Res 30:747

5. Mehta P, Gjorv OE (1982) Cement Concrete Res 12:587 
6. Bilodeau A, Malhotra VM (2000) Aci Mater J 97

7. Elsener B (2002) Cem Concr Compos 24:65

8. Fraay A, Bijen J, De Haan Y (1989) Cement Concrete Res 19:235

9. Hanehara S, Tomosawa F, Kobayakawa M, Hwang KR (2001) Cement Concrete Res 31:31

10. Duxson P, Provis JL, Lukey GC, van Deventer JSJ (2007) Cement Concrete Res 37:1590

11. Criado M, Palomo A, Fernández-Jiménez A (2005) Fuel 84:2048

12. Kumar S, Kumar R, Mehrotra S (2010) J Mater Sci 45:607. doi: 10.1007/s10853-009-3934-5

13. Šmilauer V, Hlaváček P, Škvára F, Šulc R, Kopecký L, Němeček J (2011) J Mater Sci:1. doi:10.1007/s10853-011-5601-x

14. Davidovits J (1999) Geopolymere 99:9

15. Barbosa VFF, MacKenzie KJD, Thaumaturgo C (2000) Int J Inorg. Mater 2:309

16. Rahier H, Simons W, Van Mele B, Biesemans M (1997) J Mater Sci 32:2237. doi:10.1023/A:1018563914630

17. Rahier H, Van Mele B, Biesemans M, Wastiels J, Wu X (1996) J Mater Sci 31:71. doi:10.1039/b212629j

18. Rahier H, Denayer J, Van Mele B (2003) J Mater Sci 38:3131. doi:10.1023/A:1024733431657

19. Provis JL, Van Deventer J (2009) Geopolymers: Structure, processing, properties and industrial applications. Woodhead Publ Limited, Cambridge

20. Fernández-Jiménez A, Palomo A, Criado M (2006) Mater Constr $56: 51$

21. Bakharev T (2005) Cement Concrete Res 35:1224

22. Hardjito D, Wallah SE, Sumajouw DMJ, Rangan BV (2004) Am Concr Inst Mater J 101:467

23. Fernández-Jiménez A, Palomo A (2005) Cement Concrete Res 35:1984. doi:10.1016/j.cemconres.2005.03.003

24. Škvára F, Jílek T, Kopecký L (2005) Ceram-Silikaty 49:195

25. Criado M, Fernandez-Jimenez A, de la Torre AG, Aranda MAG, Palomo A (2007) Cement Concrete Res 37:671. doi:10.1016/ j.cemconres.2007.01.013

26. Fernández-Jiménez A, Palomo A (2003) Fuel 82:2259. doi: 10.1016/S0016-2361(03)00194-7
27. Ye G (2003) The microstructure and permeability of cementitious materials. PhD thesis, Delft University of Technology, Delft

28. Ellison AH, Klemm R, Schwartz AM, Grubb L, Petrash DA (1967) J Chem Eng Data 12:607

29. Washburn EW (1921) Phys Rev 17:273

30. Duxson P, Provis JL, Lukey GC, Mallicoat SW, Kriven WM, van Deventer JSJ (2005) Colloids Surf A 269:47. doi:10.1016/j. colsurfa.2005.06.060

31. Duxson P, Fernandez-Jimenez A, Provis JL, Lukey GC, Palomo A, van Deventer JSJ (2007) J Mater Sci 42:2917. doi: 10.1007/s10853-006-0637-z

32. Sánchez de Rojas MI, Luxan MP, Frías M, García N (1993) Cement Concrete Res 23:46

33. Diamond S (1971) Cement Concrete Res 1:531

34. Feldman RF (1984) J Am Ceram Soc 67:30

35. Diamond S (2000) Cement Concrete Res 30:1517

36. Young JF, Mindess S, Darwin D (2002) Concrete. Prentice Hall, Upper Saddle River

37. Lloyd RR, Provis JL, Smeaton KJ, van Deventer JSJ (2009) Micropor Mesopor Mat 126:32. doi:10.1016/j.micromeso.2009. 05.016

38. Lloyd RR, Provis JL, van Deventer JSJ (2009) J Mater Sci 44:620. doi:10.1007/s10853-008-3078-z

39. Lloyd RR, Provis JL, van Deventer JSJ (2009) J Mater Sci 44:608. doi:10.1007/s10853-008-3077-0

40. Glukhovsky V (1967) Budivelnik Publish., Kiev

41. Criado M, Fernandez-Jimenez A, Palomo A, Sobrados I, Sanz J (2008) Micropor Mesopor Mat 109:525. doi:10.1016/j.micro meso.2007.05.062

42. Provis JL, Lukey GC, van Deventer JSJ (2005) Chem Mater 17:3075. doi:10.1021/Cm050230i

43. Rees CA, Provis JL, Lukey GC, van Deventer JSJ (2007) Langmuir 23:8170. doi:10.1021/1a700713g

44. De Silva P, Sagoe-Crenstil K (2008) Cement Concrete Res 38: 870 